\title{
NOTE
}

\section{Isolation of IPN virus serotype VR-299 from turbot in Europe}

\author{
B. Novoa $^{1}$, A. E. Toranzo ${ }^{2}$, C. P. Dopazo ${ }^{2}$, J. L. Barja ${ }^{2}$, A. Figueras ${ }^{1, \bullet}$ \\ ${ }^{1}$ Instituto de Investigaciones Marinas, CSIC, Eduardo Cabello 6, E-36208 Vigo, Spain \\ ${ }^{2}$ Dpto. Microbiología y Parasitología, Facultad de Biología, Universidad de Santiago, E-19706 Santiago de Compostela, Spain
}

\begin{abstract}
Serological and molecular properties of 2 birnaviruses isolated from Norwegian turbot Scophthalmus maximus were examined. The viral RNA and polypeptides patterns, as well as neutralization test results, showed that these strains were closely related to infectious pancreatic necrosis virus, serotype VR-299. Infectivity trials indicated no pathogenicity for turbot. This is the first isolation in Europe of VR299, the common North American virus strain of IPNV.
\end{abstract}

KEY WORDS: Birnavirus - IPNV - Scophthalmus maximus turbot

Serologically, IPNV is a heterogeneous aquatic birnavirus and all the isolates show some degree of crossreactivity (Wolf 1988). Using polyclonal antibodies, 3 major serotypes (Sp, Ab and VR-299) plus 7 additional serotypes ( $\mathrm{He}, \mathrm{Te}, \mathrm{Ja}, \mathrm{C} 1, \mathrm{C} 2, \mathrm{C} 3$ and $\mathrm{N} 1$ ) have been established. These 10 serotypes constitute serogroup A; 4 other isolates from marine shellfish represent serogroup B (Hill \& Way 1983, Christie et al. 1988).

All aquatic birnaviruses isolated from fish in the USA belong to serotype VR-299, while 4 serotypes (Ja, C1, $\mathrm{C} 2$ and $\mathrm{C} 3$ ) have been found in Canada. In Asia, isolates related to $\mathrm{Sp}, \mathrm{Ab}$ or VR-299 serotypes have been reported. While the $A b$ serotype has been isolated from a variety of fish and shellfish species, most VR299 serotype viruses from Asia have been limited to salmonids (Hedrick et al. 1985, Wattanavijan et al. 1988, Lipipun et al. 1989).

In Europe all the birnaviruses isolated from freshwater or marine fish belonged to serotypes $\mathrm{Sp}, \mathrm{Ab}, \mathrm{Te}$ and $\mathrm{He}$. The birnaviruses isolated in our laboratory since 1985 from trout, salmon and turbot with different European origins, or from our own production stock, belonged to serotypes $\mathrm{Sp}$ and $\mathrm{Ab}$ or were untypable strains (Ledo et al. 1990, 1992, Novoa et al. 1991,

- Addressee for correspondence
1992). All these IPN viruses were isolated during routine virological surveys or from diseased fish collected for examination.

Until 1988, only IPNV serotypes Ab and Sp had been isolated from fish in Norwegian salmonid farms (Håstein \& Krogsrud 1976, Krogsrud et al. 1989). A new IPNV serotype $\mathrm{N} 1$ has been reported from Norway (Christie \& Havarstein 1989) which produced high losses in Atlantic salmon Salmo salar, turbot Scophthalmus maximus L. and halibut Hippoglossus hippoglossus L., and was recovered from scallops Pecten maximus L. (Mortensen et al. 1990). In further epidemiological studies conducted in farms located along the Norwegian west coast, different IPN viruses were isolated and tested by ELISA using monoclonal antibodies. Most of them were also assigned to the new serotype N1 (Christie et al. 1990).

This report describes the first isolation of IPNV VR299 from turbot in Europe. The identification and characterization of 2 birnaviruses (TB-311 and TB-160) indicated that they belonged to VR-299, the typical North American serotype of this virus.

Materials and methods. Virus isolation and physicochemical characterization: During 1988 and 1989 imported turbot (adults and juveniles) were sent to our laboratories for virological analysis. Samples were processed for virus isolation following standard virological procedures (Amos 1985). The Chinook Salmon Embryo cell line (CHSE 214; Lannan et al. 1984) was used for all virus assays. The fish cells were cultivated at $15^{\circ} \mathrm{C}$ in Eagle's minimal essential medium (MEM) supplemented with $10 \%$ fetal bovine serum and containing $100 \mathrm{IU}$ penicillin and $100 \mu \mathrm{g}$ streptomycin $\mathrm{ml}^{-1}$.

Viral RNA electrophoresis: The RNA segments of the 2 birnaviruses from turbot were extracted and analyzed in polyacrylamide gels. Concentrated virus (pelleted at $100000 \times g$ for $1 \mathrm{~h}$ ) was treated with protei- 
nase $\mathrm{K}\left(200 \mu \mathrm{g} \mathrm{m} \mathrm{m}^{-1}\right)$ at $37^{\circ} \mathrm{C}$ for 30 to $60 \mathrm{~min}$. Samples were mixed with sample buffer, boiled for 5 min and analyzed in SDS-PAGE (Laemmli 1970) using $7.5 \%$ polyacrylamide gels, that were run for $3 \mathrm{~h}$ at $100 \mathrm{~V}$ in a Mini Protean II Electrophoresis System (BIO-RAD, USA). The RNA bands were visualized by staining with silver nitrate. The reference strains of IPNV (Sp, Ab, VR-299 and N1) together with the strain TB-306, an atypical $A b$ related virus isolated from turbot (Novoa et al. 1992), were included in the same gel for comparison. The RNA segments of a characterized aquareovirus from turbot (TRV) (Dopazo 1991) were used as molecular weight markers.

Analysis of virion polypeptides: CHSE-214 cells were infected at a multiplicity of infection of 1 virus cell $^{-1}$ with the IPNV strains. After 1 h of adsorption, MEM with $2 \%$ FBS was added and the uncovered plates were irradiated with UV light (44 ergs s${ }^{-1} \mathrm{~mm}^{-2}$ at $25 \mathrm{~cm}$ ) (Dobos \& Rowe 1977). Five hours later, $10 \mu \mathrm{Ci}$ $\mathrm{ml}^{-1}$ of $\left({ }^{35} \mathrm{~S}\right.$ )-methionine (sp. act. $1000 \mathrm{Ci} \mathrm{mmol}{ }^{-1}$ ) in methionine-free medium was added for $5 \mathrm{~h}$. Then, the cells were washed 3 times with PBS and suspended in $200 \mu \mathrm{l}$ of $0.1 \mathrm{~N} \mathrm{NaOH}, 1 \%$ SDS and $200 \mu \mathrm{l}$ of sample buffer. The preparations were subjected to SDS-PAGE on a $12 \%$ polyacrylamide gel for $5 \mathrm{~h}$ at $11 \mathrm{~mA}$. The gel was treated twice with dimethylsulfoxide (DMSO) for $30 \mathrm{~min}$, once with $20 \%$ of 2,5-Diphenyloxazole (PPO) in DMSO for $3 \mathrm{~h}$ and then washed with water. The gel was then dried and autoradiography was done on X-ray film (Kodak, USA).

Neutralization assays: The possible relationship of the turbot isolates to 4 serotypes of IPNV (Sp, Ab, VR299 and N1) was examined using specific rabbit antisera against the different serotypes. The neutralizing antibody titers were calculated by the method of Reed $\&$ Müench (1938) and expressed as the reciprocal of the highest dilution of antiserum protecting $50 \%$ of the inoculated wells.

Experimental infections: Infectivity trials were conducted in order to determine the pathogenicity of the isolated strains (TB-311 and TB-160). For comparative purposes, the North American reference serotype VR299 was included. Turbot (1 g), previously tested for virus, were injected intraperitoneally with $50 \mu \mathrm{l}$ of several doses $\left(8 \times 10^{7}, 8 \times 10^{6}, 8 \times 10^{5} \mathrm{TCID}_{50} \mathrm{ml}^{-1}\right)$ of each viral suspension; 8 fish were used per dose. The controls were inoculated with culture medium. Fish were maintained for $30 \mathrm{~d}$ at $15^{\circ} \mathrm{C}$ in $25 \mathrm{l}$ tanks using recirculated seawater with aeration. In all experiments the control and infected fish were treated the same. Dead and surviving fish were collected for virus assays.

Results and discussion. Two viruses (strains TB-311 and TB-160) were isolated from turbot and identified

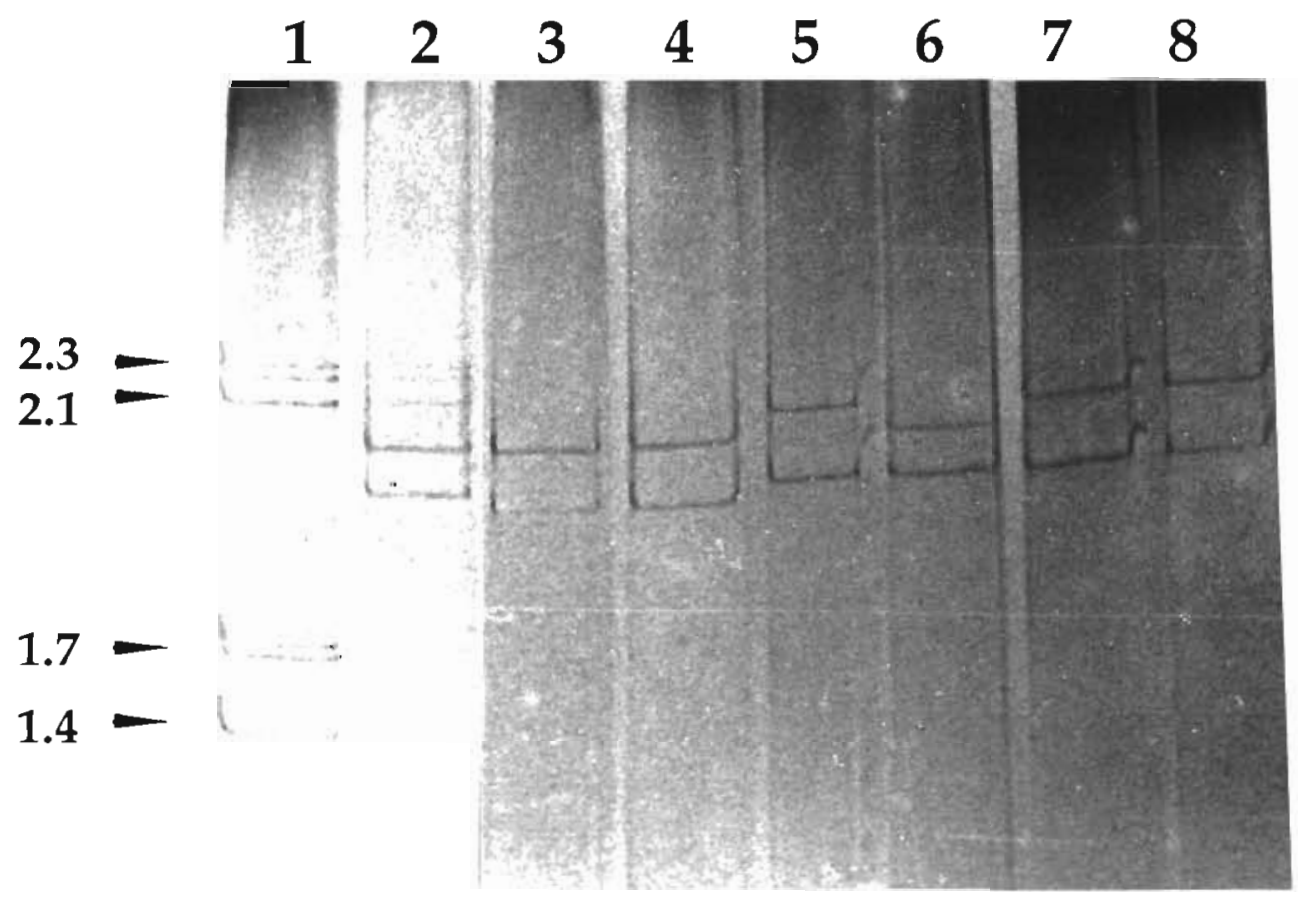

Fig. 1 RNA electrophoretic pattern of the reference strains of IPNV and turbot birnaviruses. Lane 1: molecular weight markers (RNA segments of TRV, turbol aquareovirus). Lane 2: Serotype N1 of IPNV. Lane 3: TB-306 strain isolated from turbot. Lane 4: Serotype Ab. Lane 5: Serotype VR-299. Lane 6: Serotype Sp. Lane 7: TB-311 straln isolated from turbot. Lane 8: TB-160 strain isolated from turbot 
as birnaviruses according to their physical and chemical characteristics: resistance to chloroform treatment, yellowish-green cytoplasm of infected cells stained with acridine orange which is indicative of a doubledstranded virus, neutralization by antisera against IPN virus and a bisegmented RNA genome (Fig. 1). Whereas the TB-160 strain was obtained from apparently healthy fish of 3 to $4 \mathrm{~g}$, TB-311 was found in haemorrhagic internal organs of brood stock, which suffered high mortalities.

The results of the neutralization assays are summarized in Table 1. High neutralization titers were ob- tained with VR-299 antiserum (14125 for TB-160 and 44668 for TB-311) and the reference strain VR-299. The 4 reference strains were neutralized more specifically by their respective antisera. The 4 selected reference serotypes of IPNV could be distinguished by the relative mobilities of the viral RNA as well as the viral polypeptides. The size of the RNA segments of the viral isolates from turbot were identical to those of VR299 (1.9 and $2.1 \times 10^{6}$ daltons) (Fig. 1) and the polypeptides patterns of the turbot strains were also similar to those of VR-299 (Fig. 2).

No mortalities were recorded in turbot injected with

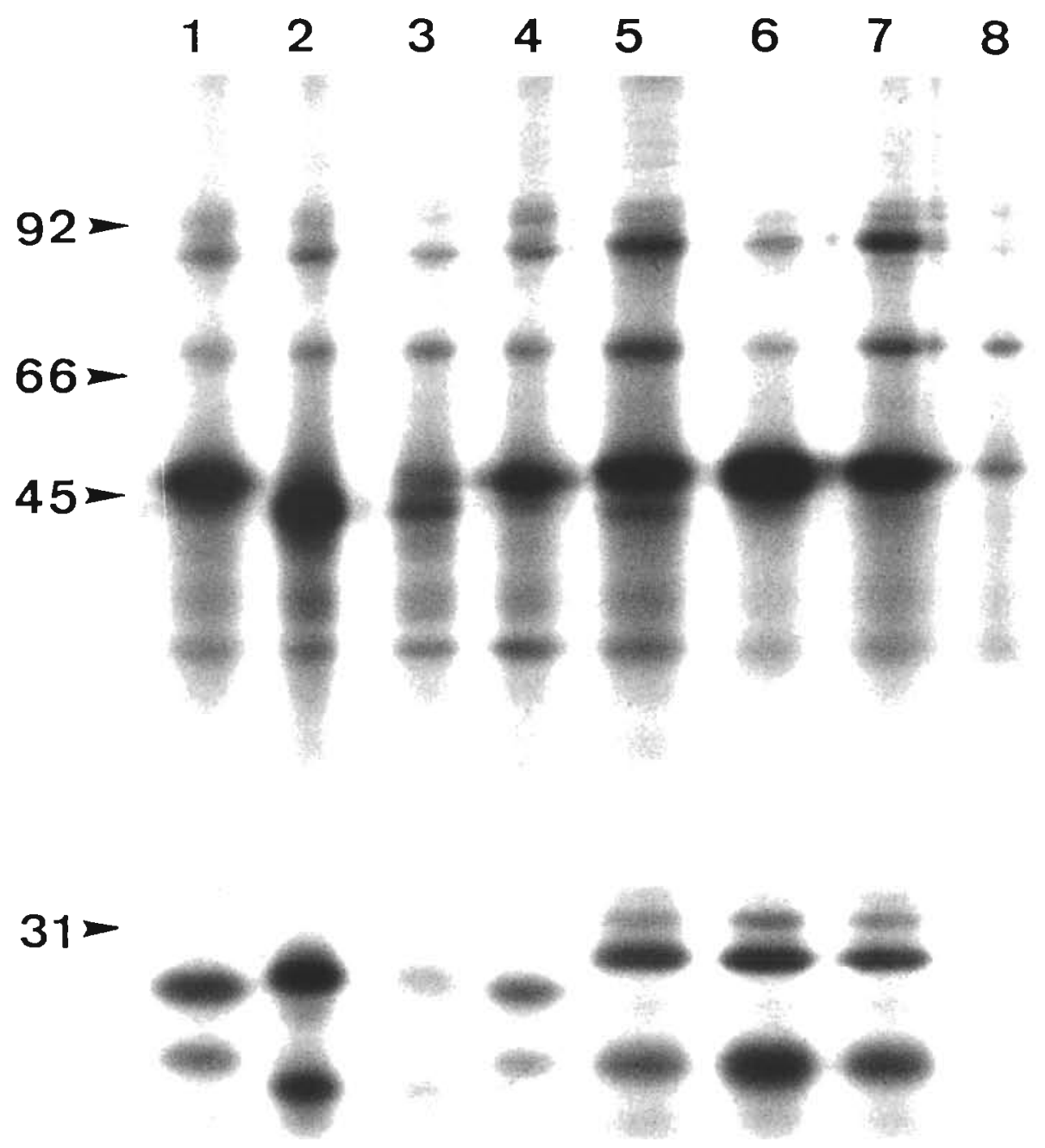

Fig. 2. Viral polypeptides of the reference strains of IPNV and the turbot birnavirus strains. Lane 1 : Serotype N1 of IPNV. Lane 2: Serotype Ab. Lane 3: TB-306 strain isolated from turbot. Lane 4: Serotype Sp. Lane 5: Serotype VR-299. Lane 6: TB-311 strain isolated from turbot. Lane 7: TB-160 strain isolated from turbot. Lane 8: uninfected cells 
Table 1. Serological relationship of the VR-299 related strains from turbot (TB-311 and TB-160) with the reference serotypes

\begin{tabular}{|c|c|c|c|c|}
\hline \multirow{2}{*}{ Virus } & \multicolumn{4}{|c|}{ Antisera } \\
\hline & $\mathrm{Sp}$ & $A b$ & VR-299 & N1 \\
\hline $\mathrm{Sp}$ & $29854^{d}$ & 7079 & 8414 & 29854 \\
\hline $\mathrm{Ab}$ & 1585 & 14125 & 4217 & 1259 \\
\hline VR-299 & 3548 & 4216 & 44668 & 2985 \\
\hline N1 & 29854 & 5957 & 8414 & 44668 \\
\hline TB-160 & 3548 & 2985 & 14125 & 2985 \\
\hline TB-311 & 7079 & 3548 & 44668 & 8413 \\
\hline
\end{tabular}

the 2 strains of birnavirus during $30 \mathrm{~d}\left(\mathrm{LD}_{50}\right.$ values higher than $8 \times 10^{7} \mathrm{TCID}_{50}$ ), indicating that, under experimental conditions, they were not pathogenic for turbot. The North American reference strain VR-299 was also not virulent for turbot. Only in the case of the turbot strain TB-311 was virus recovered from survivors, where the titer of $10^{3} \mathrm{TCID}_{50} \mathrm{~g}^{-1}$ of tissue suggested that a carrier state had been established. Studies are being conducted to determine if other fish species are susceptible to these turbot isolates.

The isolation of 2 viruses from fish in Europe with the characteristics of IPNV serotype VR-299 alters the established distribution of the basic serotypes of aquatic birnavirus. Traditionally, the $\mathrm{Sp}$ and $\mathrm{Ab}$ serotypes were considered to belong to European waters whereas the VR-299 was considered a North American strain. However an IPN virus from southern flounder Paralichthys lethostigma with the characteristics of the Ab serotype has been reported in the USA (McAllister et al. 1984), and viruses belonging to the serogroup II (usually found in marine shellfish) were isolated from salmonids and marine fish (Olesen et al. 1988, Ahne et al. 1989).

To date, the birnaviruses isolated from fish and molIuscs cultured in our area were predominantly Sp strains (Ledo et al. 1990, Dopazo 1991, Rivas et al. 1992). Moreover, bimaviruses recovered from imported stocks of turbot from European countries belonged to the $\mathrm{Sp}, \mathrm{Ab}$ serotypes or were untypable strains (Ledo et al. 1990. Novoa et al. 1992, unpubl. data). Similar results were obtained when wild fish and sediments were monitored to detect reservoirs of IPN viruses (Rivas et al. 1992). Castric et al. (1987) associated the Ab serotype with mortalities of turbot in France. Therefore, the presence of the VR-299 serotype in turbot from farms surrounded by floating cages of salmon, in which this serotype was never detected, is striking Although the origin of VR-299 in Europe is unknown, as is the case with the N1 strain (Mortensen et al. 1990), transmission from feral animals, i.e. molluscs, crustaceans, cannot be ruled out.
Acknowledgements. We thank R. P. Hedrick and J. Castric for providing the antisera and the reference viral strains used in this study. We thank A. Ledo for providing the biological material from which the virus was isolated. We also wish to thank J. R. Caldas and 1. L. Caride for technical assistance and cooperation. This work was supported by Grants MAR 89-0270 and AGF-93-0769-C02-02 from the Dirección General de Investigación Científica y Técnica (CICYT) and XUGA 20008A-91 from Xunta de Galicia, Spain. Beatriz Novoa acknowledges the Ministerio de Educación y Ciencia (Spain), for research fellowship.

\section{LITERATURE CITED}

Ahne, W., Jørgensen, P. E. V., Olesen, N. J., Fischer-Scherl, T. Hoffmann, R. (1989). Aquatic birnaviruses: virus of the serogroup II isolated from an IPN outbreak in brook trout (Salvelinus fontinalis). Bull. Eur. Ass. Fish Pathol. 9 (1) $14-16$

Amos, A. H. (1985). Procedures for the detection and identification of certain fish pathogens, 3rd edn. Fish Health Section. American Fisheries Society, Corvallis

Castric, J., Baudin-Laurencin, F., Coustans, M. F., Auffret, M. (1987). Isolation of infectious pancreatic necrosis virus $A b$ serotype from epizootic in farmed turbot, Scophthalmus maximus. Aquaculture 67: 117-126

Christie, K. E., Havarstein, L. S. (1989). A new serotype of infectious pancreatic necrosis virus (IPN $\mathrm{N}_{1}$ ). In: Ahne, W. Kurstak, E. (eds.) Viruses of lower vertebrates. SpringerVerlag, Berlin, p. 279-283

Christie, K. E., Havarstein, L. S., Djupvik, H. O., Endresen, C. (1988). Characterization of a new serotype of infectious pancreatic necrosis virus isolated from Atlantic salmon. Arch. Virol. 103: 167-177

Christie, K. E., Ness, S., Djupvik, H. O. (1990). Infectious pancreatic necrosis virus in Norway: partial serotyping by monoclonal antibodies. J. Fish Dis. 13: 323-327

Dobos, P., Rowe, D. (1977). Peptide map comparison of infectious pancreatic necrosis virus specific polypeptides. J. Virol. 32: 805-820

Dopazo, C. P. (1991). Caracterización de birnavirus y rotavirus de peces: propiedades biológicas, serológicas y moleculares. Tesis Doctoral, Universidad de Santiago de Compostela

Hâstein, T., Krogsrud, J. (1976). Infectious pancreatic necrosis. First isolation of virus from fish in Norway. Acta vet. scand. 17: 109-111

Hedrick, R. P., Eaton, W. D., Fryer, J. L., Hah, Y. C., Park, J. W. Hong, S. W. (1985). Biochemical and serological properties of birnavirus isolated from fish in Korea. Fish Pathol. 20: 463-468

Hill, B. J., Way, K. (1983). Serological classification of fish and shellfish birnaviruses. In: Abstracts of First International Conference of the European Association of Fish Pathologists, Plymouth, p. 10

Krogsrud, J. H. J., Hăstein, T, Rønningen, K. (1989). Infectious pancreatic virus in Norwegian fish farms. In: Ahne, W. Kurstak, E. (eds.) Viruses of lower vertebrates. SpringerVerlag, Berlin, p. 284-291

Laemmli, U. K. (1970). Cleavage of structural proteins during the assembly of the head of bacteriophage T4. Nature 227 : $680-685$

Lannan, C. N., Winton, J. R., Fryer, J. L. (1984). Fish cell lines: establishment and characterization of nine cell lines from salmonids. In Vitro 20: 671-676

Ledo, A., Barja, J. L., Toranzo, A. E. (1992). A strategy for con- 
trolling the spread of viruses via imported eggs. Bull. Eur. Ass. Fish Pathol. 12 (3): 90-93

Ledo, A., Lupiani, B., Dopazo, C. P., Toranzo, A. E., Barja, J. L (1990). Fish viral infections in northwest of Spain Microbiología 6: 21--29

Lipipun, V., Caswell-Reno, P., Hsu, Y.-L., Wu, J.-L., Tung M.-C., Reno, P. W., Wattanavijarn, W., Nicholson, B. L. (1989). Antigenic analysis of Asian aquatic birnavirus isolates using monocional antibodies. Fish Pathol. 24 (3) 155-160

McAllister, P. E., Newman, M. W., Sauber, J. H., Owens, W. J. (1984). Isolation of infectious pancreatic necrosis virus (serotype $A b$ ) from diverse species of estuarine fish. H felgoländer Meeresunters. 37: 317-328

Mortensen, S. H., Hjeltnes, B., Rodseth, O., Krogsrud, J., Christie, K. E. (1990). Infectious pancreatic necrosis virus, serotype $N_{1}$, isolated from Norwegian halibut (Hippoglossus hippoglossus), turbot (Scophthalmus maximus) and scallops (Pecten maximus). Bull. Eur. Ass. Fish Pathol. $10(2): 42-43$

Novoa, B., Figueras, A. J., Ledo, A., Barja, J. L., Toranzo, A. E. (1991). Incidence of birnavirus in cultured turbot (Scophthalmus maximus L.) in Northwest Spain. American

Responsible Subject Editor: F. M. Hetrick, College Park, Maryland, USA
Fisheries Society, Fish Health Section, Newsletter 19 (2): $2-3$

Novoa, B., Figueras, A. J., Puentes, C. F., Ledo, A., Toranzo, A. E. (1992). Characterization of a birnavirus isolated from diseased turbot cultured in Spain. Dis. aquat. Org. 15 $163-169$

Olesen, N. J., Vestergård Jørgensen, P. E., Bloch, B., Mellergaard, S. (1988). Isolation of an IPN-like virus belonging to the serogroup II of the aquatic birnavirus from dab, Limanda limanda L. J. Fish Dis. 11:449-451

Rivas, C., Cepeda, C., Vila, C., Dopazo, C. P., Ledo, A., Barja, J. L. (1992). Marine environment as reservoir of poikilothermic viruses. In: Vivares, C. P. (ed.) Abstracts of the 5th International Colloquium on Pathology in Marine Aquaculture. Biocim, Montpellier, p. 26.

Reed, L. J, Müench, H. (1938). A simple method of estimating fifty per cent end-points. Am. J. Hyg. 27: 493-497

Wattanavijan, W., Torchy, C., Tangtronpiros, J., de Kinkelin, P. (1988). Isolation of a birnavirus belonging to Sp serotype, from South East Asia fishes. Bull. Eur. Ass. Fish Pathol. 8 (5): 106-107

Wolf, K. (1988). Fish viruses and fish viral diseases. Cornell University Press, Ithaca

Manuscript first received: March 1, 1993

Revised version accepted: April 29, 1993 